\title{
PERAN LEMBAGA PENDIDIKAN WAKAF DALAM MEMBENTUK KARAKTER BERTOLERANSI
}

\author{
Hari Candra \\ Naila Amania \\ Universitas Islam Negeri (UIN) Riau \\ e-mail:amanianaila@gmail.com
}

\begin{abstract}
The importance of the Quranic principle in the Qur>an is actually nothing but a departure from social reality, that diversity and diversity are social facts. Nevertheless, for some people it still assumes that diversity is a threat, but for some others diversity undermines the monism that is inherent in tribal, national and religious clothes. The number of social conflicts that occur in society today is pointed out as an indication that some parties are still unwilling and not ready to accept the diversity even many ways that are used in rejecting the fitrah and destiny of God, which is by forming a religious understanding that rejects various forms of understanding that lead to diversity include the diversity of ideology and contemporary-modern thought theory. Seeing this fact, it is important to immerse tolerance within the framework of diversity in the life of society, nation and state. Tolerance is needed and become a pillar in realizing a life of mutual respect for each other so as to create a harmonious life. To realize it all required the role of educational institutions is no exception wakaf educational institutions where it is considered to have a noble and great role in the history of human life that
\end{abstract}


is shaping the character of learners who are capable, independent, creative, democratic, responsible and tolerant tailored to the concept of curriculum based on values of tolerance according to Islamic teachings.

Keywords: Waqf Institution, Character Education, and Tolerance

\section{Pendahuluan}

Menyebar luasnya gerakan radikal yang dibelakangi oleh pergerakan beratas namakan ajaran agama seperti itu tentu sangat meresahkan kalangan masyarakat secara luas. Tidak lagi condong kepada aksi pengerusakan ataupun kriminalitas semata seperti pengeboman dan ancaman teror bom yang dilakukan pergerakan sejenis sebelumnya, namun lebih kepada mengarah ke ajaran, paham dan aqidah.Dalam aksinya juga, pergerakan ini dapat mengakibatkan orang disekitar kita yang menjadi incaran berubah sikap menjadi karakter yang tidak bisa kita pahami. Mereka akan menjadi orang yang sepertinya tidak pernah kita kenal sebelumnya bahkan mungkin akan menghilang keberadaannya dari masyarakat. Hal ini akibat doktrinisasi yang kemudian dilakukan perekrutan secara intensif dan efektif oleh para anggota gerakan radikal (Aliakov, t.th: 6). Gerakan ini secara keseluruhan menganut paham "salafisme radikal", yakni berorientasi pada penciptaan kembali masyarakat salaf (generasi Nabi Muhammad dan para sahabatnya) dengan cara-cara keras dan radikal. Bagi mereka, Islam pada masa kaum salaf inilah yang merupakan Islam paling sempurna (Rahmat, 2005: xi).

Radikalisme sejatinya merupakan fenomena yang mempunyai akar sejarah panjang dalam kebudayaan Islam. Secara istilah, radikalisme adalah fanatik kepada satu pendapat serta menegasikan pendapat orang lain, mengabaikan terhadap kesejarahan Islam, tidak dialogis, suka mengkafirkan kelompok lainyang tak sepaham, dan tekstual dalam memahami teks agama 
dengan tanpa mempertimbangkan tujuan esensial syariat yaitu maqashid al-syari'at (Masqudi, 2013: 2).

Berkaitan dengan pengaruh radikalisme yang belakangan ini menyeruak, dalam hal faktor pendidikan, sekalipun pendidikan bukanlah faktor langsung yang dapat menyebabkan munculnya gerakan terorisme, akan tetapi dampak yang dihasilkan dari suatu pendidikan yang keliru juga sangat berbahaya. Untuk itu pendidikan agama khususnya yang harus lebih diperhatikan. Ajaran agama yang mengajarkan toleransi, kesantunan, keramahan, membenci pengrusakan, dan menganjurkan persatuan tidak sering didengungkan.

Selain itu, kondisi kemiskinan juga mengakibatkan terpuruknya pendidikan umat Islam yang harus dientaskan dengan segera, dan salah satunya adalah dengan meningkatkan dan memperbaiki kualitas pendidikan melalui pemanfaatan dana hasil wakaf produktif (Kasdi, 2014: 117). Disinilah peran lembaga wakaf sebagai salah satu pengelola wakaf bagi masyarakat berfungsi untuk mencapai maksud dan tujuan tertentu, baik di bidang pendidikan, keagamaan, sosial dan lainnya. Sehubungan dengan hal tersebut, untuk meningkatkan kualitas pendidikan diperlukan adanya lembaga pendidikan berbasis wakaf seperti pesantren dan madrasah dimana mengajarkan pemahaman pendidikan agama yang bertoleransi. Dengan ini, maka peran lembaga pendidikan mempunyai tanggungjawab yang besar dalam mengubah karakter dan menanamkan nilai toleransi yang ada dalam Islam kepada masyarakat untuk menangkal dampak negatif dari jaringan radikal.

Berkaitan dengan masalah diatas, maka penulis dalam menyusun karya tulis ilmiah ini ingin menjawab dua pokok masalah, yaitu: Pertama, bagaimanakah peran wakaf untuk pendidikan dalam menangkal radikalisme.Kedua, bagaimanakah membentuk pendidikanberkarakter yang bertoleransi melalui lembaga pendidikan. 


\section{Pembahasan}

\section{Pengertian wakaf}

Secara etimologi wakaf memiliki arti al-waqf (wakaf), alhabs, (menahan), dan at-tasbil (berderma untuk sabilillah). Kata alwaqf adalah bentuk masdar (gerund) dari ungkapan waqfu asy-syai', yang berarti menahan sesuatu (Kasdi, 2013; 5). Disebut menahan karena wakaf ditahan dari kerusakan, penjualan, dihibahkan dan semua tindakan yang tidak sesuai dengan tujuan wakaf (Athoillah, 2014: 18). Sedangkan menurut terminologi wakaf adalah menahan harta, baik secara abadi maupun sementara, untuk dimanfaatkan langsung atau tidak langsung dan diambil manfaat hasilnya secara berulang-ulang di jalan kebaikan, umum maupun khusus ((Athoillah, 2014: 14).

Wakaf menurut Undang-Undang Nomor 41 Tahun 2004 tentang Wakaf, dijelaskan bahwa wakaf adalah perbuatan hukum wakif untuk memisahkan dan/atau menyerahkan sebagian harta benda miliknya untuk dimanfaatkan selamanya atau untuk jangka waktu tertentu sesuai dengan kepentingannya guna keperluan ibadah dan/atau kesejahteraan umum menurut syariah (Badan Wakaf Indonesia (BWI), 2015: 4).

Wakaf merupakan pranata keagamaan dalam Islam yang memiliki hubungan langsung secara fungsional dengan upaya pemecahan masalah-masalah sosial dan kemanuisaan, seperti pengentasan kemiskinan dan pemberdayaan ekonomi umat (Rozalinda, 2016: 1). Wakaf termasuk salah satu bentuk filantropi (kedermawanan), selain zakat, infaq dan sedekah yang senantiasa diharapkan pengamalannya, seperti terlihat dalam pesan-pesan ajaran Islam. Dengan demikian, berwakaf adalah perbuatan baik yang sangat dianjurkan agama.

\section{Manajemen wakaf}

Dalam perwakafan, pengelola wakaf atau nadzir sangat membutuhkan manajemen dalam menjalankan tugasnya. Manajemen ini digunakan untuk mengatur kegiatan pengelolaan 
wakaf, menghimpun wakaf uang dan menjaga hubungan baik antara nadzir, wakif dan masyarakat. Manajemen diperlukan sebagai upaya agar kegiatan pengelolaan wakaf dapat berjalan secara efektif dan efisien.

Dengan demikian manajemen wakaf merupakan proses membuat perencanaan, pengorganisasian, kepemimpinan dan pengawasan berbagai usaha dan nadzir, kemudian menggunakan semua sumber daya organisasi untuk mencapai sasaran. Oleh karena itu, setiap manajer wakaf atau nadzir harus menjalankan keempat fungsi tersebut didalam organisasi sehingga hasilnya merupakan satu kesatuan yang sistematik (Rozalinda, 2016: 72- 74).

Dari beberapa pembahasan diatas uraian masing-masing fungsi dari manajemen tersebut, yakni sebagai berikut:

1. Perencanaan (Planning) yaitu merupakan aspek administrasi yang bersifat khusus, dan keberhasilan perencanaan ini sangat bergantung pada standar dan informasi yang akurat (Ranupandojo, 1996: 59). Perencanaan ini berisi rumusan tindakan-tindakan yang penting untuk mencapai hasil yang diinginkan sesuai dengan maksud dan tujuan yang ditetapkan. Ini berarti seorang manajer wakaf memikirkan terlebih dahulu sasaran dan tindakan berdasarkan metode, rencana, dan logika. Karena perencanaan akan mengarahkan tujuan organisasi wakaf dan menetapkan prosedur terbaik untuk mencapai tujuan organisasi tersebut (Rozalinda,2016: 77);

2. Pengorganisasian (Organizing) yaitu mempersiapkan kerangka kerja manajemen. Ini merupakan aspek administrasi yang mendukung keberhasilan pelaksanaan rencana, sebab salah satu tugas pokok kegiatan mengorganisasi yaitu menyeleksi orang-orang yang akan melaksanakan rencana itu (Ranupandojo, 1996: 60).Dengan adanya pengorganisasian memungkinkan untuk mengatur sumber daya insani nadzir wakaf guna mencapai tujuan 
yang telah ditentukan dengan segala potensi yang ada secara efektif dan efisien. Dalam proses pengorganisasian wakaf, manajer wakaf atau ketua nadzir mengalokasikan sumber daya organisasi sesuai dengan rencana yang telah dibuat berdasarkan suatu kerangka kerja organisasi dan atau struktur organisasi.Dalam manajemen lembaga wakaf, pengorganisasian berfungsi untuk merumuskan dan menetapkan tugas, serta menetapkan prosedur yang diperlukan. Kemudian, menetapkan struktur organisasi dengan menunjukkan adanya garis kewenangan dan tanggung jawab masing-masing nadzir, kegiatan perekutan nadzir, penyeleksian, pelatihan, pengembangan sumber daya manusia, dan kegiatan penempatan sumber daya manusia pada posisi yang paling tepat pada lembaga pengelola wakaf ((Rozalinda, 2016: 80-81);

3. Kepemimpinan (Leading) yaitu proses mengarahkan dan mempengaruhi aktivitas yang berkaitan dengan pekerjaan dari anggota kelompok atau seluruh organisasi (Issakh dan Wiryawan, 2015: 95). Berkaitan dengan wakaf, dalam fungsi atau tahapan kepemimpinan yang harus dilakukan adalah melaksanakan proses kepemimpinan, pembimbingan, dan pemberian motivasi kepada nadzir yang direkrut agar dapat bekerja secara efektif dan efisien dalam pencapaian tujuan wakaf. Kepemimpinan ditujukan agar program wakaf produktif yang telah disusun bisa dijalankan oleh seluruh pihak dalam organisasi serta memotivasi agar semuanya dapat menjalankan tanggung jawab dengan penuh kesadaran dan produktivitas yang tinggi. Seorang pemimpin memiliki peran yang krusial dalam menentukan maju mundurnya sebuah perusahaan. Untuk itu, ketua nadzir, baik nadzir perorangan, organisasi maupun yayasan harus memiliki kemampuan mengarahkan dan memimpin anggota atau bawahannya untuk maju dalam rangka meraih tujuan bersama (Rozalinda, 2016: 81-82); 
4. Pengawasan (Controlling) yaitu proses untuk memastikan bahwa aktivitas sebenarnya sesuai dengan yang direncanakan. Mengendalikan disebut juga merupakan proses untuk meyakinkan manajer bahwa tindakan yang dilakukan oleh anggota organisasi adalah selaras dengan sasaran yang telah ditetapkan (Issakh dan Wiryawan, 2015: 97).Berkaitan dengan manajemen wakaf, dalam fungsi pengawasan yang dilakukan nadzir adalah mengevaluasi pencapaian tujuan dan target kegiatan sesuai dengan standar atau prinsip investasi dalam perspektif ekonomi syariah. Mengambil langkah klarifikasi dan koreksi atas penyimpangan yang mungkin ditemukan. Kemudian, ia melakukan berbagai alternatif atau solusi atas berbagai masalah yang terkait dengan pencapaian tujuan pengelolaan wakaf (Rozalinda, 2016: 86).

\section{Peran wakaf untuk pendidikan}

Secara umum kontribusi wakaf dibidang pendidikan sudah cukup banyak. Diantara pemanfaatan hasil wakaf produktif yang paling banyak pengaruhnya adalah pemberdayaan wakaf produktif untuk pengembangan pendidikan. Wakaf untuk pendidikan dimaksudkan sebagai aset wakaf yang diberdayakan secara produktif dan diharapkan mendatangkan keuntungan atau hasil untuk dimanfaatkan bagi kepentingan pendidikan dan pengembangan keilmuan.

Wakaf produktif adalah wakaf yang pokok barangnya digunakan untuk kegiatan produksi dan hasilnya diberikan sesuai dengan tujuan wakaf, artinya harta wakaf tidak langsung atau digunakan untuk kemaslahatan umat dalam bentuk ubudiyah yakni ibadah (Qahaf, 2005: 5). Wakaf produktif dapat direalisasikan dengan wakaf benda tidak bergerak, seperti tanah, gedung, lahan pertanian dan bahkan wakaf benda bergerak, seperti uang dapat dikelola secara produktif dapat dikembangkan 


\section{Hari Candra dan Naila Amania}

untuk membiayai sektor pendidikan, kesehatan dan kesejahteraan umat pada umumnya.

Salah satu contoh pemanfaatan harta benda wakaf yaitu pengalihan tanah atau tukar guling (ruislag) untuk tujuan produktif dengan mengembangkan model wakaf modern, menerapkan teknik manajemen modern pada wakaf yang tidak bertentangan dengan prinsip-prinsip syari'ah (Kasdi, 2015: 37). Tanah yang tidak dimanfaatkan untuk bangunan lembaga pendidikan bisa didesain dan dilengkapi dengan fasilitas-fasilitas yang produktif seperti pertokoan, swalayan, perkantoran, atau ruang pertemuan selama lokasi tanah tersebut memungkinkan untuk dimanfaatkan untuk maksud-maksud tersebut. Hasil atau keuntungan dari kegiatan bisnis tersebut dapat dipergunakan sebagai sumber dana abadi bagi kegiatan pendidikan dan pengembangan keilmuan.

Pengembangan dan pemberdayaan wakaf untuk pendidikan sudah berkembang di negara-negara Islam lainnya. Manfaatnya sangat besar bagi kemajuan pendidikan, ilmu pengetahuan dan juga bidang-bidang lainnya. Salah satu wakaf produktif sangat besar peranannya untuk pengembangan pendidikan yaitu alAzhar Cairo Mesir. Pemanfaatan wakaf produktif al-Azhar yakni dengan memfasilitasi sarjana dan mahasiswa melalui sarana dan prasarana yang memadai, beasiswa, serta gaji pegawai dan dosen al-Azhar. Bahkan mereka juga bisa melakukan berbagai riset, penulisan buku, penerjemah dan menyelesaikan studi gratis yang dibiayai dari wakaf produktif (Kasdi, 2015: 132).Wakaf tidak hanya mendukung pengembangan ilmu pengetahuan, tetapi juga menyediakan berbagai fasilitas yang diperlukan mahasiswa maupun masyarakat.

\section{Pendidikan karakter}

Pendidikan secara etimologi berasal dari bahasa Yunani yaitu paedagogic yang artinya pendidikan yang diberikan kepada seorang anak. Sedangkan secara terminologi pendidikan adalah upaya penyiapan manusia supaya hidup dengan kehidupan 
yang sempurna. Dalam Kamus Besar Bahasa Indonesia (KBBI), pendidikan diartikan sebagai proses pengubahan sikap dan tata laku seseorang atau sekelompok orang dalam usaha mendewasakan manusia melalui upaya pengajaran dan latihan; proses, perbuatan, dan cara-cara pendidik (Kasdi, 2015: 67). Sedangkan pengertian karakter adalah watak, sifat, atau hal-hal yang memang sangat mendasar yang ada pada diri seseorang. Adapun pengertian lain karakter adalah sifat batin manusia yang mempengaruhi segenap pemikiran dan perbuatannya. Banyak yang memandang atau mengartikannya identik dengan kepribadiannya (Majid dan Andayani, 2013: 12).

Karakter sebagaimana didefinisikan oleh Ryan dan Bohlin mengandung tiga unsur pokok, yaitu mengetahui kebaikan (knowing the good), mencintai kebaikan (loving the good), dan melakukan kebaikan (doing the good), artinya knowing the good mudah diajarkan sebab pengetahuan bersifat kognitif saja, yang selanjutnya harus ditumbuhkan loving the good, yakni bagaimana mencintai kebajikan menjadi engine yang bisa membuat orang senantiasa berbuat kebaikan. Sehingga tumbuh kesadaran bahwa, orang ingin melakukan perilaku kebajikan karena dia cinta dengan perilaku kebajikan itu. Setelah terbiasa melakukan kebajikan, maka doing the good itu berubah menjadi kebiasaan (Wiyani, 2012: 68).

Dalam pendidikan karakter, kabaikan itu sering kali dirangkum dalam sederet sifat-sifat baik. Dengan demikian, maka pendidikan karakter adalah proses pemberian tuntunan kepada peserta didik untuk menjadi manusia seutuhnya yang berkarakter dalam dimensi hati, piker, raga, serta rasa dan karsa. Pendidikan karakter dapat dimaknai dengan penddikan nilai, pendidikan budi pekerti, pendidikan moral, pendidikan watak, yang bertujuan untuk membrikan keputusan baik-buruk, memlihara apa yang baik, dan mewujudkan kebaikan itu dalam kehidupan sehari-hari dengan sepenuh hati (Wiyani, 43-44). Upaya ini juga memberi jalan untuk menghargai persepsi dan 


\section{Hari Candra dan Naila Amania}

nilai-nilai pribadi yang ditampilkan di lingkungan sekolah. Fokus pendidikan karakter adalah pada tujuan-tujuan etika, tetapi praktiknya meliputi penguatan kecakapan-kecakapan yang penting yang mencakup pekembangan sosial peserta didik (Majid dan Andayani, 2013: 11).

\section{Peran pendidikan agama dalam pembentukan karakter}

Hal yang perlu diperhatikan bagi integrasi antara pendidikan agama dan pendidikan karakter adalah kaitan antara keyakinan agama dan kebersamaan hidup dalam masyarakat yang bhinneka seperti Indonesia. Nilai-nilai keagamaan tidak dapat dijadikan sebagai dasar bagi kehidupan bersama dimana terdapat berbagai macam perbedaan keyakinan iman di dalam masyarakat. Hal ini justru memiliki unsur yang lebih dalam dan fundamental bagi pribadi kesepakatan hidup bersama tidak dapat ditentukan oleh keyakinan pemeluk agama tertentu dalam sebuah masyarakat (Majid dan Andayani, 2013: 64).

Nilai-nilai agama dan nilai demokrasi bukanlah sesuatu yang harus dipertentangkan. Jika dipahami secara lebih utuh dan integral, nilai-nilai ini dapat memberikan sumbangan yang efektif bagi sebuah penciptaan masyarakat yang stabil dan mampu bekerjasama dalam mencapai tujuan bersama. Hal ini sesungguhnya yang menjadi semangat dalam pasalpasal pancasila. Oleh karena itu, pendidikan agama merupakan dukungan dasar yang tak tergantikan bagi keutuhan pendidikan karakter, karena dalam beragama terkandung nilai-nilai luhur yang mutlak kebaikan dan kebenarannya (Majid dan Andayani, 2013: 65).

Dalam pandangan Islam, pembentukan karakter (character building) ini dalam kajian lebih dalam yang dilakukan para ulama klasik dan kontemporer disimpulkan bahwa akhlak mulia sebagai hasil dari character buildingadalah jantung ajaran Islam. Maka tak diragukan lagi pembentukan akhlak mulia merupakan tujuan tertinggi bagi setiap lembaga pendidikan Islam (Majid 
dan Andayani, 2013: 108).Sebab akhlak merupakan fondasi dasar sebuah karakter diri. Sehingga pribadi yang berakhlak nantinya akan menjadi bagian dari masyarakat yang baik pula. Akhlak dalam Islam juga memiliki nilai yang mutlak karena persepsi antara akhlak baik dan buruk memliki nilai yang dapat diterapkan pada kondisi apapun. Tentu saja, hal ini sesuai dengan fitrah manusia yang menempatkan akhlak sebagai pemelihara eksistensi manusia sebagai makhluk yang paling mulia. Akhlaklah yang membedakan karakter manusia dengan makhluk yang lainnya. Tanpa akhlak, manusia akan kehilangan derajat sebagai hamba Allah SWT paling terhormat (Syafri, 2012: 68).

\section{Pendidikan karakter yang bertoleransi}

Toleransi merupakan salah satu bagian dari pendidikan karakter yang berkaitan dengan pembentukan karakter, konsep pendidikan karakter yang mengedepankan sembilan pilar karakter, yakni karakter cinta Tuhan dan segenap ciptaan-Nya, kemandirian dan tanggung jawab, kejujuran/amanah, diplomatis, hormat dan santun, dermawan, suka tolong-menolong dan gotong royong, percaya diri dan kepemimpinan dan keadilan, baik dan rendah hati, toleransi, kedamaian dan kesatuan. Toleransi merupakan sikap dan tindakan yang menghargai perbedaan agama, suku, etnis, pendapat, sikap, dan tindakan orang lain yang berbeda dengan dirinya(Syafri, 2012: xi-xii). Toleransi mengandung maksud untuk merealisasikan dengan menghormati agama, moralitas dan lembaga-lembaga mereka serta menghargai pendapat orang lain dan perbedaan-perbedaan yang ada di lingkungannya tanpa harus berselisih dengan sesamanya hanya karena berbeda keyakinan atau agama.Dengan memiliki karakterkarakter tersebut maka masyarakat akan memiliki kekuatan untuk menyaring budaya-budaya asing yang masuk disamping juga masyarakat akan melangkah maju dan menjadi terbaik di era globalisasi ini. 


\section{Lembaga pendidikan wakaf}

Peranan wakaf dalam pengembangan pendidikan melalui lembaga pendidikan wakaf sangat besar manfaatnya. Hal ini juga merupakan momentum yang tepat dalam menerapkan peran dan fungsi pendidikan, sehingga lebih terasa manfaatnya bagi masyarakat. Mayoritas lembaga wakaf biasanya dibuat untuk lembaga pendidikan sepertipesantren dan madrasah, dimana mengajarkan pemahaman pendidikan agama yang menanamkan nilai toleransi. Artinya, pendidikan toleran harus dibangun pula di atas karakter anak didik yang mengendepankan kerendahan hati, kemurahan hati, keramahan, dan kesopanan dalam menghargai orang lain.

Selain itu, di dalam pesantren dan madrasah juga menerapkan struktur atau pola organisasi kurikulum pendidikannya bersifat efektif, yakni memadukan kurikulum yang bersifat subject curriculum, yaitu terkait dengan pentingnya memahami ilmu agama; correlated curriculum, yaitu terkait dengan sifat materi agama Islam, yang berkaitan antara satu dan lainnya; integrated curriculum, yaitu terkait dengan sifat ajaran Islam yang tidak mengenal pemisahan antara ilmu agama dan ilmu agama lain, dan antara ilmu agama dengan ilmu umum; core atau intracurriculum, yaitu kurikulum yang bersifat inti atau dasar, terkait dengan akidah, ibadah, dan akhlak mulia; dan extra-curriculum, yaitu terkait dengan berbagai kegiatan yang benuansa agamis. Selain itu, kurikulum pesantren dan madrasah juga harus belajar berdasar pada konsep kurikulum modern, yaitu kurikulum yang melihat seluruh kegiatan baik didalam maupun diluar kelas sebagai satu kesatuan yang saling menopang (Nata, 2016: 114).

Dengan menerapkan kurikulum yang tepat maka hasil tujuan yang dikehendaki akan tercapai. Karena kurikulum merupakan inti dari bidang pendidikan dan memiliki pengaruh terhadap seluruh kegiatan pendidikan. Mengingat pentingnya kurikulum dalam bidang pendidikan dan kehidupan manusia, maka penyusunan kurikulum tidak dapat dilakukan secara 
sembarangan. Penyusunan kurikulum membutuhkan landasanlandasan yang kuat, yang didasarkan pada hasil-hasil pemikiran dan penelitian yang mendalam. Landasan pengembangan kurikulum tersebut meliputi landasan filosofis (dasar manusia), landasanpsikologis (perilaku individu dalam konteks belajar), landasan sosial-budaya (pola kehidupan dan berperilaku antar anggota masyarakat) dan landasan ilmu pengetahuan dan teknologi (dalam bidang transportasi dan komunikasi). Penyusunan kurikulum yang tidak didasarkan pada landasan yang kuat dapat berakibat fatal terhadap kegagalan pendidikan itu sendiri. Dengan sendirinya akan berakibat pula terhadap kegagalan proses pengembangan manusia (Sulistyorini dan Fathurrohman, 2014: 78).

\section{Lembaga pendidikan wakaf dan uapaya menangkal radikalisme}

Keterpurukan ekonomi yang dialami oleh sebagian lapisan masyarakat mengakibatkan ketidakmampuan dalam mengeyam pendidikan. Hal ini akan berakibat keterpurukan pengetahuan bagi warga yang kurang mampu. Mereka tidak akan cukup dibekali oleh ilmu pengetahuan yang sedang berkembang dan juga akan lebih rentan terhadap pengaruh-pengaruh yang datang dari pihak lain. Termasuk juga akan mudah diprovokasi oleh paham-paham radikal. Selain itu, tingkat pemahaman agama yang rendah juga dapat mengakibatkan lebih rentan terpengaruh ajaran-ajaran yang menyesatkan.

Keterlibatan berbagai pihak dalam menangani masalah radikalisme dan bahkan aksi terorisme sangat diharapkan. Tujuannya adalah untuk mempersempit ruang gerak radikalisme dan terorisme, serta kalau perlu menghilangkan sama sekali. Dalam konteks di atas, disinilah peran pendidikan dan lembaga pendidikan sangat penting dalam menghentikan laju radikalisme. 


\section{Hari Candra dan Naila Amania}

Sehubungan adanya hal tersebut dapat diantisipasi dengan peranan wakaf, karenawakaf sangat besar dalam menunjang pelaksanaan pendidikan. Dengan wakaf masyarakat mendapatkan kemudahan dalam menuntut ilmu. Sebab wakaf pendidikan tidak terlalu menuntut banyak biaya bagi pelajar-pelajar sehingga bagi mereka baik miskin atau kaya mendapat kesempatan yang sama. Jika didirikan lembaga pendidikan yang didanai dari harta wakaf, akan memberikan harapan sekaligus tantangan baru bagi perwujudan masyarakat yang berperadaban.

Wakaf dapat menjadi penjamin keperluan pendidikan untuk masyarakat ketika wakaf itu dikelola secara profesional dengan pengelolaan yang produktif. Wakaf dalam bentuk lembaga pendidikan dapat dimulai dari pendidikan anak usia dini, pendidikan dasar, pendidikan menengah, hingga pendidikan tinggi. Termasuk dalam hal ini adalah wakaf untuk lembagalembaga pendidikan non formal seperti pesantren dan madrasah yang didalamnya mengajarkan konsep kurikulum yang toleran. Wakaf juga menjadi sumber pendanaan bagi fasilitas-fasilitas yang merupakan pelengkap bagi layanan pendidikan, seperti laboratorium, perpustakaan, penyediaan buku-buku rujukan, lembaga-lembaga penelitian, dan sebagainya.

Pendidikan dan lembaganya memang dapat dijadikan pintu masuk untuk mengawali proses deradikalisasi agama yang sedang mewabah di negara kita. Sebab, lembaga pendidikan berperan sebagai sebuah proses social engineering untuk melakukan penetrasi secara halus (penetration of pacifque) tentang pandangan dunia, nilai dan gagasan kepada peserta didik, sehingga mendorong terjadinya proses transformasi pada ranah pemikiran, kesadaran, sikap dan perilaku. Disini, diajarkan pendidikan yang menjunjung tinggi prinsip saling menghargai perbedaan, kerukunan, perdamaian, kesantunan, dan manifestasi akhlak mulia yang lainnya.Dengan demikian langkah-langkah deradikalisasi diperlukan untuk membangun pendidikan yang toleran. 


\section{Pendidikan karakter bertoleransi melalui lembaga pendidikan wakaf}

Besarnya pengaruh lingkungan dalam membentuk karakter pribadi seorang individu memicu setiap orang untuk belajar menjadi individu yang lebih baik. Pendidikan karakter sangat penting dibangun agar anak didik menjadi manusia yang berkarakter, yaitu beriman dan bertakwa kepada Tuhan Yang Maha Esa, cakap, kreatif, mandiri, dan menjadi warga negara yang demokratif dan bertanggung jawab. Hal tersebut dapat dilakukan dengan cara menempatkan diri pada lingkungan yang mendudukung dan membuat seseorang menjadi individu yang mampu bersikap dan bersosialisasi dengan lingkungannya. Lingkungan yang baik tersebut diharapkan dapat menjadi lebih baik dengan cara menanamkan kebiasaan-kebiasaan yang baik sehingga diharapkan kebiasaan tersebut akan terus berlanjut dan dapat diterapkan dalam kehidupan.

Rendahnya sikap toleransi terhadap sesama ternyata juga berimbas pada berbagai sendi kehidupan.Pendidikan toleran saat ini sangat mendesak untuk diterapkan di lembaga pendidikan pesantren, madrasah, dan lembaga pendidikan Islam lainnya di tengah-tengah maraknya indoktrinasi. Karena, peran lembaga pendidikan seperti pesantren dan madrasah sangatlah penting dalam usaha pencapaian tujuan pendidikan karakter dengan terbentuknya karakter yang baik dan unggul.Dalam konteks ini, pendidikan karakter merupakan usaha lembaga pendidikan yang dilakukan secara bersama dan terus menerus oleh pimpinan, guru, serta seluruh warga lembaga pendidikan untuk membentuk akhlak dan kepribadian peserta didik melalui berbagai nilai yang diambil dari ajaran agama, sosial, budaya bangsa, serta nilai-nilai luhur secara umum, termasuk kurikulum dan lingkungan internal maupun eksternal.

Untuk itu, pendidikan yang bertoleransi menekankan nilainilai kebijaksanaan dan mewujudkan cinta kasih antar sesama dalam masyarakat yang penuh perbedaan. Pendidikan toleran juga 


\section{Hari Candra dan Naila Amania}

merupakan proses yang mendorong anak didik bersedia melihat pendapat orang lain sebagai hal yang layak dihormati. Upaya mewujudkan pendidikan toleran menghadapi problem berupa mengakarnya teologi intoleransi terutama berkaitan dengan radikalisme, inimenjadi problem pendidikan Islam yang terjadi di lembaga-lembaga Islam pada umumnya.Untuk itu pentingnya sebuah lembaga pendidikan yang mengajarkan pendidikan karakter dengan konsep kurikulum yang menanamkan nilai-nilai toleransi di dalam Islam. Karena kedudukan kurikulum menjadi penting, dengan kurikulum sebagai individu yang berkembang akan mendapatkan manfaat. Hal itu maka akan menghasilkan masyarakat atau akademik yang lebih baik.

Menyadari pentingnya masalah tersebut, maka sudah waktunya pendidikan mengambil alih kembali fungsinya dalam mendidik dan membentuk karakter manusia dengan menanamkan nilai-nilai toleransi yang berpedoman pada al-Quran dan nilainilai luhur Pancasila.

\section{Simpulan}

Kekerasan atas nama agama semakin marak terjadi akibat paham radikalisasi. Dengan maraknya paham radikal tersebut, maka pendidikan toleran saat ini sangat penting untuk diterapkan melalui pesantren, madrasah dan lembaga pendidikan Islam lainnya. Ini karena di dalam pesantren dan madrasah diajarkan pendidikan yang menjunjung tinggi prinsip saling menghargai perbedaan, kerukunan, perdamaian, kesantunan, dan manifestasi akhlak mulia yang lain.Dalam hal ini, mayoritas pesantren dan madrasahdibangun dengan dana hasil wakaf yang dikelola secara profesional dengan manajemen pengelolaan yang produktif, sebab peranan wakaf dalam mengembangkan kualitas pendidikan melalui lembaga pendidikan wakaf sangat besar manfaatnya.Disinilah wakaf pendidikan dipilih karena instrumenini sangat potensial untuk dikembangkan dan mencetak kader-kader unggulan. 
Lembaga pendidikan pesantren dan madrasah yang dibangun dengan dana wakaf memiliki peran sangat penting dalam mengurangi paham radikalisme. Itu terbukti dengan adanya struktur kurikulum yang diterapkan, yaitu subject curriculum, correlated curriculum, integrated curriculum, core atau intra-curriculum, dan extra-curriculum yang didalamnya membentuk pendidikan karakter dan mengajarkan konsep kurikulum yang toleran.

Untuk itu pentingnya sebuah lembaga pendidikan yang mengajarkan pendidikan karakter dengan konsep kurikulum yang menanamkan nilai-nilai toleransi di dalam Islam. Kedudukan kurikulum menjadi penting, karena kurikulum sebagai individu yang berkembang akan mendapatkan manfaat. Dengan ini maka akan menghasilkan masyarakat atau akademik yang lebih baik. Dalam hal ini mengandung arti bahwa setiap upaya pembangunan harus selalu diarahkan untuk memberi dampak positif terhadap pengembangan karakter. Ketika suatu bangsa mampu menghargai dan menjunjung tinggi pendidikan, maka hal tersebut akan menjadi penjaga keseimbangan yang secara langsung akan berfungsi sebagai kontrol sosial.

\section{Daftar Pustaka}

Abdul Majid dan Dian Andayani, Pendidikan Karakter Perspektif Islam, Remaja Rosdakarya, Bandung, 2013.

Abdurrahman Kasdi, Fiqih Wakaf: Dari Wakaf Klasik Hingga Wakaf Produktif, Idea Press, Yogyakarta, 2013.

Abdurrahman Kasdi, "Model Pemberdayaan Wakaf Produktif di Indonesia", ZISWAF, Vol. 1, No. 1, STAIN Kudus, 2014.

Abdurrahman Kasdi, Wakaf Produktif Untuk Pendidikan: Model Pengelolaan Wakaf Produktif Al-Azhar Asy-Syarif Cairo Mesir, Idea Press, Yogyakarta, 2015. 
Abuddin Nata, Inovasi Pendidikan Islam, Salemba Diniyah, Jakarta, 2016.

Athoillah, Hukum Wakaf: Wakaf Benda Bergerak dan Tidak Bergerak dalam Fikih dan Peraturan Perundang-undangan di Indonesia, Yrama Widya, Bandung, 2014.

Badan Wakaf Indonesia (BWI), Himpunan Peraturan PerundangUndangan Tentang Wakaf, Badan Wakaf Indonesia (BWI), Jakarta, 2015.

Heidjarachman Ranupandojo, Teori dan Konsep Manajemen, UPP AMP YKPN, Yogyakarta, 1996.

Henki Idris Issakh dan Zahrida Wiryawan, Pengantar Manajemen, Edisi 2, In Media, Jakarta, 2015.

Irwan Masqudi, "Deradikalisasi Pendidikan Islam Berbasis Khazanah Pesantren", Jurnal Pendidikan Islam, Vol. II, No. 1, Pesantren Asslafiyyah Mlangi, Yogyakarta, 2013.

M. Imdadun Rahmat, Arus Baru Islam Radikal: Transmisi Revivalisme Islam Timur Tengah Ke Indonesia, Erlangga, Jakarta, 2005.

Muhammad Aliakov, "Berkembangnya Radikalisme di Perguruan Tinggi", STIMIK AMIKOM, Yogyakarta, t.t.

Mundzir Qahaf, Manajemen Wakaf Produktif, Terj. Muhyidin Mas Rido, Khalifa, Jakarta, 2005.

Novan Ardy Wiyani, Manajemen Pendidikan Karakter: Konsep Dan Implementasinya Di Sekolah, Pedagogia, Yogyakarta, 2012.

Rozalinda, Manajemen Wakaf Produktif, Raja Grafindo Persada, Jakarta, 2016.

Sulistyorini dan Muhammad Fathurrohman, Esensi Manajemen Pendidikan Islam: Pengelolaan Lembaga Untuk Meningkatkan Kualitas Pendidikan Islam, Teras, Yogyakarta, 2014.

Ulil Amri Syafri, Pendidikan Karakter Berbasis Al-Quran, Rajawali, Jakarta, 2012. 